\title{
Carbon Dioxide Absorption and Release Properties of Pyrolysis Products of Dolomite Calcined in Vacuum Atmosphere
}

\author{
Fei Wang, ${ }^{1}$ Toshihiro Kuzuya, ${ }^{2}$ Shinji Hirai, ${ }^{2}$ Jihua Li, ${ }^{1}$ and Te Li ${ }^{1}$ \\ ${ }^{1}$ Key Laboratory of Tropical Crop Products Processing of Ministry of Agriculture, Agriculture Products Processing Research Institute, \\ Chinese Academy of Tropical Agricultural Sciences, Zhanjiang 524001, China \\ ${ }^{2}$ Division of Engineering for Composite Function, Muroran Institute of Technology, 27-1 Mizumoto-cho, Muroran, \\ Hokkaido 050-8585, Japan
}

Correspondence should be addressed to Toshihiro Kuzuya; 610653717@qq.com

Received 16 April 2014; Accepted 25 June 2014; Published 16 July 2014

Academic Editor: Alessandro D’Annibale

Copyright (C) 2014 Fei Wang et al. This is an open access article distributed under the Creative Commons Attribution License, which permits unrestricted use, distribution, and reproduction in any medium, provided the original work is properly cited.

The decomposition of dolomite into $\mathrm{CaO}$ and $\mathrm{MgO}$ was performed at $1073 \mathrm{~K}$ in vacuum and at $1273 \mathrm{~K}$ in an $\mathrm{Ar}$ atmosphere. The dolomite calcined in vacuum was found to have a higher specific surface area and a higher micropore volume when compared to the dolomite calcined in the Ar atmosphere. These pyrolysis products of dolomite were reacted with $\mathrm{CO}_{2}$ at $673 \mathrm{~K}$ for $21.6 \mathrm{ks}$. On the absorption of $\mathrm{CO}_{2}$, the formation of $\mathrm{CaCO}_{3}$ was observed. The degree of absorption of the dolomite calcined in vacuum was determined to be above $50 \%$, which was higher than the degree of absorption of the dolomite calcined in the Ar atmosphere. The $\mathrm{CO}_{2}$ absorption and release procedures were repeated three times for the dolomite calcined in vacuum. The specific surface area and micropore volume of calcined dolomite decreased with successive repetitions of the $\mathrm{CO}_{2}$ absorption and release cycles leading to a decrease in the degree of absorption of $\mathrm{CO}_{2}$.

\section{Introduction}

Mixed powders of $\mathrm{CaO}$ and $\mathrm{MgO}$ obtained by the pyrolysis of dolomite ore are considered as promising materials for the absorption of $\mathrm{CO}_{2}$ [1] because of their porous structure, reusability, and low cost [2]. The mixed powders react reversibly with $\mathrm{CO}_{2}$, as shown in (1) below:

$$
\mathrm{CaO}(\mathrm{s})+\mathrm{MgO}(\mathrm{s})+2 \mathrm{CO}_{2}(\mathrm{~g})=\mathrm{CaMg}\left(\mathrm{CO}_{3}\right)_{2}
$$

A typical sequestration process of $\mathrm{CO}_{2}$ by a sorbent involves the use of two circulating fluidized beds. One is operated in the temperature range $673-973 \mathrm{~K}$ as a carbonator, and the other is operated in the temperature range 1023$1223 \mathrm{~K}$ as a cracker [2]. In theory, the volume of $\mathrm{CO}_{2}$ absorbed by the mixed powders from room temperature to $1100 \mathrm{~K}$ is 800-1600 times larger than the volume absorbed by pure $\mathrm{CaO}$ and $\mathrm{MgO}$ powders; the absorbed $\mathrm{CO}_{2}$ can be released when the powders are heated above $1100 \mathrm{~K}$. Therefore, dolomite can be used for the selective absorption of $\mathrm{CO}_{2}$ from gas mixtures of $\mathrm{H}_{2}$ and $\mathrm{CO}_{2}$ such as those evolved from a water-gas shift reaction (2) or the decomposition of dimethyl ether (DME). Consider the following:

$$
\mathrm{CO}+\mathrm{H}_{2} \mathrm{O}=\mathrm{CO}_{2}+\mathrm{H}_{2}
$$

There have been several reports on the properties of dolomite as a $\mathrm{CO}_{2}$ absorbent. The absorption performance of the pyrolysis products of dolomite depends on a number of factors such as the calcination conditions, $\mathrm{CO}_{2}$ flow rate, absorption temperature, and atmosphere. Among these factors, the calcination conditions strongly affect the absorption performance, because the porous structure of dolomite, which facilitates the diffusion of $\mathrm{CO}_{2}$, is formed and refined during the decomposition procedure [3, 4]. Kristóf-Makó and Juhász [5] indicated that the decomposition of dolomite was divided into two steps, which was restrained by the reaction temperature and atmosphere; Beruto et al. (2002) reported that the dolomite was decomposed at high $\mathrm{CO}_{2}$ pressure in the temperature range of $913-973 \mathrm{~K}$. And they found that the kinetic analysis of the TG curves yields a total apparent enthalpy for the decomposition equal to 
$440 \pm 10 \mathrm{~kJ} \cdot \mathrm{mol}^{-1}$ for the partial decomposition to the calcite and $\mathrm{MgO}$. Rodriguez-Navarro et al. [6] reported the $\mathrm{MgCO}_{3}$ pseudophase in dolomite was first decomposed, leaving the undecomposed $\mathrm{CaCO}_{3}$ pseudophase at first step in air or in a $\mathrm{CO}_{2}$ atmosphere. On the analysis of the kinetics of partial decomposition of dolomite as a function of the $\mathrm{CO}_{2}$ pressure, Galai et al. [7] found that the rate-limiting step in the growth of $\mathrm{MgO}$ and $\mathrm{CaCO}_{3}$ can be controlled by the diffusion of magnesium through $\mathrm{MgO}$ phase surface. Gallucci et al. [8] introduced a mathematical model for the absorption of $\mathrm{CO}_{2}$ by the pyrolysis products of dolomite, based on the assumption that the solid particles of dolomite are made up of very small spherical grains. For the absorption process, which can be described as the carbonation of $\mathrm{CaO}-$ $\mathrm{MgO}$ mixture, the authors found good agreement between the model predictions and experimental data, as testified by the scanning electron microscopy (SEM) images of dolomite and the thermogravimetry (TG) curves of $\mathrm{CO}_{2}$ absorption process.

Stendardo and Foscolo [9] discussed a mathematical model of a heterogeneous gas-solid phase reaction taking place within very small spherical grains of the particles of a reactant. Their model was able to encapsulate changes in the structure of the spherical grains, by the introduction of a variable diffusion coefficient of the gaseous reactant. Beruto et al. $[10,11]$ found that a humid atmosphere causes the pyrolysis products of dolomite to show a high activity for $\mathrm{CO}_{2}$ absorption. They proved that though $\mathrm{H}_{2} \mathrm{O}(\mathrm{g})$ cannot change the properties of the solid products formed out of $\mathrm{MgO}, \mathrm{CaCO}_{3}$, and solid solutions of $\mathrm{MgO}$ in $\mathrm{CaCO}_{3}$, it can increase the growth rate of the $\mathrm{MgO}$ particles. During hydration, $\mathrm{CaO}$ particles are not stable and they transform to $\mathrm{Ca}(\mathrm{OH})_{2}$ (3) and (4). Ewing et al. [12] introduced the pressure of $\mathrm{CO}_{2}$ which could influence the change of specific surface area of $\mathrm{CaO}$. [13] And sintering of the $\mathrm{CaO}$ is negligible at $650^{\circ} \mathrm{C}$ in $\mathrm{CO}_{2}$ pressures of $\leq 0.1$ torr, but sintering is pronounced in $\mathrm{CO}_{2}$, at 9 torr pressure. Beruto and Searcy [14] reported that the reactive crystalline material was synthesized during incomplete decomposition of calcite in vacuum atmosphere, with three-layer structure. And the layer of a poorly crystalline material was present between the undecomposed $\mathrm{CaCO}_{3}$ and a layer of normal polycrystalline $\mathrm{CaO}$. Consider

$$
\begin{gathered}
\mathrm{CaO}(\mathrm{s})+\mathrm{H}_{2} \mathrm{O}(\mathrm{g})=\mathrm{Ca}(\mathrm{OH})_{2}(\mathrm{~s}) \\
\mathrm{Ca}(\mathrm{OH})_{2}(\mathrm{~s})+\mathrm{CO}_{2}(\mathrm{~g})=\mathrm{CaCO}_{3}(\mathrm{~s})+\mathrm{H}_{2} \mathrm{O}(\mathrm{g})
\end{gathered}
$$

A lower decomposition temperature has a positive influence on the $\mathrm{CO}_{2}$ absorption properties of Ca-based absorbents, because particle agglomeration is minimized, leading to the preservation of their highly porous structure [3]. According to the theory of reaction rates, a decrease in the concentration of $\mathrm{CO}_{2}$ in the reactants can lower the decomposition temperature of dolomite. Since previous reports on dolomite had not focused on this aspect, we employed vacuum conditions for the calcination of dolomite and studied the corresponding effects on the absorption of $\mathrm{CO}_{2}$.

In this study, the $\mathrm{CO}_{2}$ absorption and release properties of the pyrolysis products of dolomite calcined in an $\mathrm{Ar}$
TABLE 1: Chemical composition of dolomite (wt\%).

\begin{tabular}{ccccccc}
\hline $\mathrm{CaO}$ & $\mathrm{MgO}$ & $\mathrm{SiO}_{2}$ & $\mathrm{Al}_{2} \mathrm{O}_{3}$ & $\mathrm{Fe}_{2} \mathrm{O}_{3}$ & Others & $\begin{array}{c}\text { Loss } \\
\text { of fusion }\end{array}$ \\
\hline 34.53 & 17.92 & 0.29 & 0.08 & 0.04 & 0.76 & 46.38 \\
\hline
\end{tabular}

atmosphere and under vacuum were evaluated using TG. In addition, changes in their specific surface area and micropore volume were also investigated in a cyclic absorption and release procedure.

\section{Experimental Procedure}

Crystallized dolomite powder (Yoshizawa Lime Industry Co., Ltd., Japan) with an average particle diameter of $45 \mu \mathrm{m}$ and a specific surface area of $4.76 \mathrm{~m}^{2} \cdot \mathrm{g}^{-1}$ was used to prepare the $\mathrm{CO}_{2}$ absorbents. The chemical components of dolomite are listed in Table 1.

The $\mathrm{CO}_{2}$ absorption and release properties were evaluated by thermogravimetric analysis (TGA) and differential thermal analysis (DTA) performed using a thermogravimetry instrument (TG: TG-DTA2000S, MAC Science CO., Ltd., Kanagawa, Japan). For sample preparation, dolomite was calcined in an Ar atmosphere at $1273 \mathrm{~K}$ and separately in vacuum at $1073 \mathrm{~K}$ in the TG apparatus. The heating rate was $10 \mathrm{~K} \cdot \mathrm{min}^{-1}$, and the flow rate of Ar was $100 \mathrm{~mL} \cdot \mathrm{min}^{-1}$. After calcination, the pyrolysis products of dolomite were allowed to cool to room temperature in an Ar atmosphere. For absorption tests, the samples were heated up to $673 \mathrm{~K}$ in an Ar atmosphere with a heating rate of $10 \mathrm{~K} \cdot \mathrm{min}^{-1}$ and were kept at this temperature for $21.6 \mathrm{ks}$ in $\mathrm{a} \mathrm{CO}_{2}$ atmosphere. The flow rate of $\mathrm{CO}_{2}$ was $300 \mathrm{~mL} \cdot \mathrm{min}^{-1}$. For cyclic tests, the release and absorption steps were repeated three times under the same conditions.

The structure of the samples was studied with an X-ray diffractometer (Rint-UltIma+, Rigaku Corp., Tokyo, Japan) having a monochromatic $\mathrm{CuK} \alpha$ radiation as the source. The specific surface area and micropore volume of the samples were measured using the Brunauer-Emmett-Teller (BET)

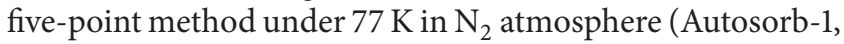
Quantachrome, FL, USA). SEM and energy-dispersive X-ray spectroscopy (EDS) analysis of the samples were performed using a SEM apparatus (JSM-6610LV, JEOL, Tokyo, Japan).

The degree of absorption was determined using the following equation under the assumption that the $\mathrm{CO}_{2}$ absorption reaction proceeds according to (1). The $\mathrm{CO}_{2}$ absorption per gram of $\mathrm{CO}_{2}$-saturated samples was calculated from (6) and was estimated to be $0.8702 \mathrm{~g}$ :

$$
\begin{gathered}
W_{\mathrm{CO}_{2}}=\left(\frac{W_{\mathrm{CaO}}}{\mathrm{F} \cdot \mathrm{W} \cdot \mathrm{CaO}}+\frac{W_{\mathrm{MgO}}}{\mathrm{F} \cdot \mathrm{W} \cdot \mathrm{MgO}}\right) \times \mathrm{F} \cdot \mathrm{W} \cdot \mathrm{CO}_{2} \\
W_{s}=\frac{W_{\mathrm{CO}_{2}}}{W_{\text {dolomits }}-W_{\text {Loss }}}=0.4666 \mathrm{~g}
\end{gathered}
$$

where $W_{\mathrm{CO}_{2}}$ is the stoichiometric absorption weight of $\mathrm{CO}_{2}$ for pure dolomite and $W_{\mathrm{CaO}}, W_{\mathrm{MgO}}$, and Wdolomite are 
the weights of $\mathrm{CaO}, \mathrm{MgO}$, and calcined dolomite, respectively. F.W. ${ }_{\mathrm{CaO}}, \mathrm{F} . \mathrm{W} \cdot \mathrm{MgO}$, and F.W. ${ }_{\mathrm{CO}_{2}}$ are the molecular weights $\left(\mathrm{g} \cdot \mathrm{mol}^{-1}\right)$ of $\mathrm{CaO}, \mathrm{MgO}$, and $\mathrm{CO}_{2}$, respectively. $W_{S}$ is the theoretical maximum degree of absorption of $\mathrm{CO}_{2}$ and Wloss is the loss of fusion, as shown in Table 1. The actual degree of absorption was calculated from the following equation:

$$
A_{N}=\frac{\Delta W}{\left(W_{S} \times W_{N-1}\right)}
$$

where $A_{N}$ represents the actual cyclic degree of absorption of $\mathrm{CO}_{2}, N$ is the number of absorption cycles, $\Delta W$ is the change in weight during the absorption process, and $W_{N-1}$ is the weight of the sample after calcination.

\section{Results and Discussion}

3.1. XRD Analyses of Dolomite and Its Pyrolysis Products. The X-ray diffraction (XRD) patterns of the dolomite raw material and its pyrolysis products fabricated under different conditions are shown in Figure 1. Figure 1(a) shows that calcium magnesium carbonate $\left(\mathrm{CaMg}\left(\mathrm{CO}_{3}\right)_{2}\right)$ and $\mathrm{CaCO}_{3}$ were found in the dolomite raw material. The dolomite sample calcined in an $\mathrm{Ar}$ atmosphere at $1173 \mathrm{~K}$ contained a mixture of $\mathrm{CaCO}_{3}, \mathrm{CaO}$, and $\mathrm{MgO}$, as shown in Figure 1(b). However, when the calcination temperature was raised to $1273 \mathrm{~K}$, the characteristic peaks of $\mathrm{CaCO}_{3}$ disappeared possibly due to its decomposition into $\mathrm{CaO}$ and $\mathrm{CO}_{2}$ (Figure $1(\mathrm{c})$ ). Figure $1(\mathrm{~d})$ shows the effect of a reduced decomposition temperature on the structure of the dolomite raw material.

3.2. Thermal Decomposition of Dolomite. The TG results shown in Figure 2 corroborate well with the results of the XRD analyses. The TG curves of dolomite samples calcined under different conditions showed a weight loss of approximately $45 \%$, which corresponds to the estimated weight loss of dolomite when it is completely decomposed into three components ((9) and (10)). For the dolomite sample calcined in vacuum, decomposition started at $800 \mathrm{~K}$, which was lower than the decomposition temperature of dolomite calcined in an Ar atmosphere. As reported from Silcox et al. [15], the relationship between calcination temperature and equilibrium decomposition pressure is shown as (8). Calcium carbonate will be decomposed when its decomposition pressure above the carbon dioxide pressure around the particles; so in vacuum atmosphere, inert decomposition pressure is always higher than external carbon dioxide pressure, and the reaction will happen in relative lower temperature. Moreover,

$$
P_{\text {eq }}=4.137 \times 10^{7} \exp \left(-\frac{20474}{T}\right) \text { atm } .
$$

Previous studies have reported that dolomite decomposes in two steps at a high partial pressure of $\mathrm{CO}_{2}$. In the first step, $\mathrm{CaCO}_{3}, \mathrm{MgO}$, and $\mathrm{CO}_{2}$ are formed, as shown in (9), and

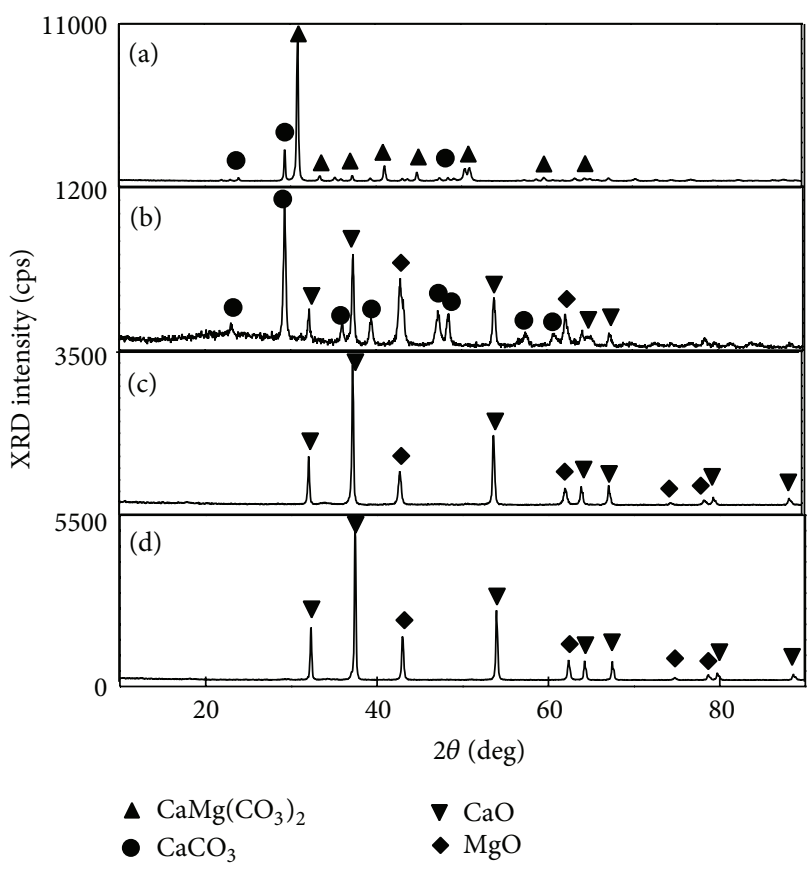

FIGURE 1: XRD patterns of the dolomite raw material and its pyrolysis products fabricated under different conditions. (a) Raw material, (b) pyrolysis products calcinated in an Ar atmosphere at $1173 \mathrm{~K}$ for $3.6 \mathrm{ks}$, (c) pyrolysis products calcinated in an $\mathrm{Ar}$ atmosphere at $1273 \mathrm{~K}$ for $3.6 \mathrm{ks}$, and (d) pyrolysis products calcinated in vacuum at $1073 \mathrm{~K}$ for $3.6 \mathrm{ks}$.

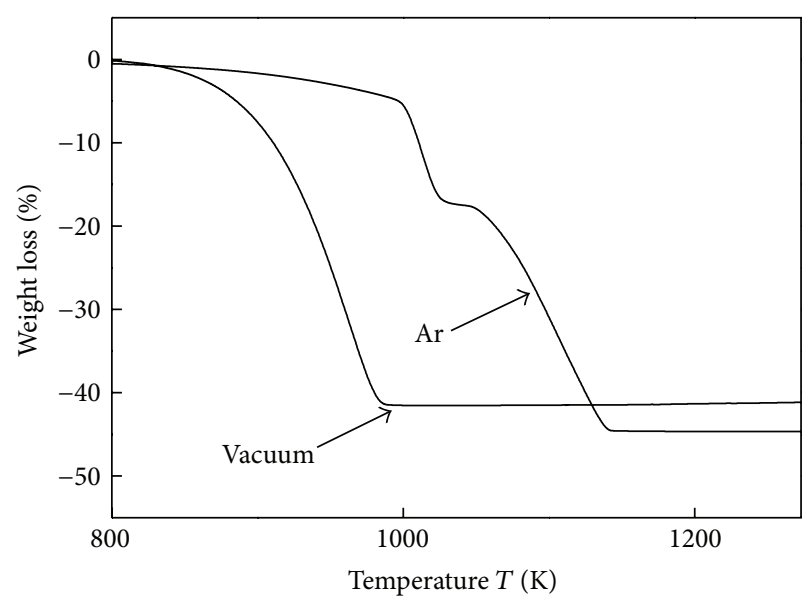

Figure 2: TG curves of dolomite decomposition in an Ar atmosphere and vacuum.

subsequently, $\mathrm{CaCO}_{3}$ also decomposes into $\mathrm{CaO}$ and $\mathrm{CO}_{2}$ (10) $[5,10,11]$

$$
\begin{aligned}
\mathrm{CaCO}_{3} \cdot \mathrm{MgCO}_{3}= & \mathrm{CaCO}_{3}(\mathrm{~s}) \\
& +\mathrm{MgO}(\mathrm{s})+\mathrm{CO}_{2}(\mathrm{~g})(973-1073 \mathrm{~K})
\end{aligned}
$$

$$
\mathrm{CaCO}_{3}=\mathrm{CaO}(\mathrm{s})+\mathrm{CO}_{2}(\mathrm{~g})(>1173 \mathrm{~K})
$$




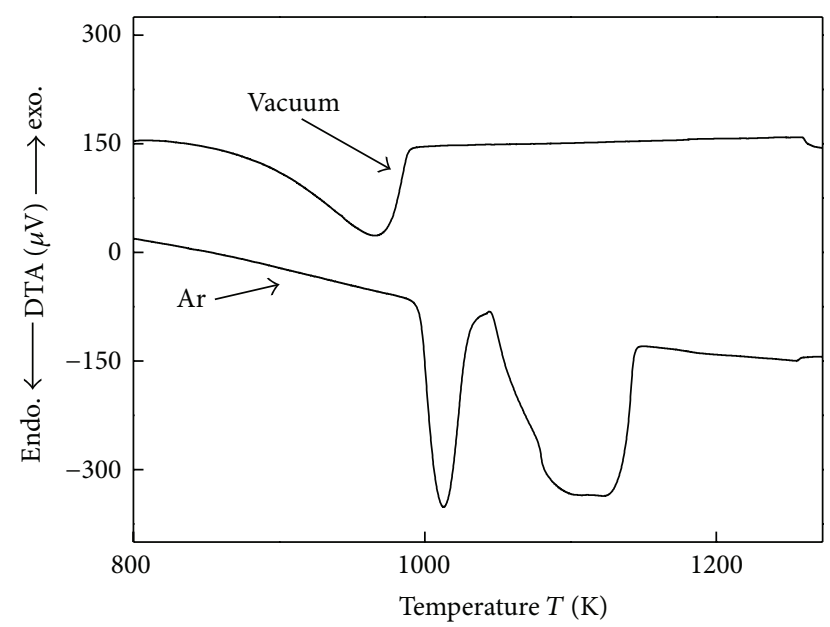

FIgURE 3: DTA curves of dolomite decomposition in an Ar atmosphere and vacuum.

For the calcination of dolomite in Ar and vacuum atmosphere, the DTA results are shown in Figure 3. The two endothermic peaks (A) and (B) can be attributed to the enthalpy changes of the decomposition reactions (9) and (10), respectively. The Gibbs free energy change of the decomposition reaction of dolomite can be represented by the following equations:

$$
\begin{aligned}
& \Delta \mathrm{G}=\Delta G_{0}+R T \times \ln \left\{\frac{\left(a_{\mathrm{CaCO}_{3}} \times a_{\mathrm{MgO}} \times p_{\mathrm{CO}_{2}}\right)}{a_{\mathrm{CaMg}\left(\mathrm{CO}_{3}\right)_{2}}}\right\} \\
& \Delta \mathrm{G}=\Delta G_{0}+R T \times \ln \left\{\frac{\left(a_{\mathrm{CaO}} \times a_{\mathrm{MgO}} \times p_{\mathrm{CO}_{2}}\right)}{\left.a_{\mathrm{CaMg}_{\left(\mathrm{CO}_{3}\right)_{2}}}\right\},}\right.
\end{aligned}
$$

where $\Delta G, \Delta G^{\circ}, T, a$, and $p$ represent the Gibbs free energy change $\left(\mathrm{kJ} \cdot \mathrm{mol}^{-1}\right)$, standard free energy change $\left(\mathrm{kJ} \cdot \mathrm{mol}^{-1}\right)$, temperature $(\mathrm{K})$, activity, and partial pressure, respectively. The activities of $\mathrm{CaCO}_{3}, \mathrm{MgCO}_{3}, \mathrm{MgO}$, and $\mathrm{CaO}$ were all assumed to be 1 . Figure 4 illustrates the dependence of the decomposition temperature of dolomite on the partial pressure of $\mathrm{CO}_{2}$ for reactions in (9) and (10), which was determined from the thermodynamic data collected by Barin et al. $[16,17]$. The decomposition temperature decreased with the decrease in the partial pressure of $\mathrm{CO}_{2}\left(p_{\mathrm{CO}_{2}}\right)$. This trend can also be seen in the results shown in Figures 2 and 3.

Figures 5 and 6 show the SEM images and the EDS analysis results of the dolomite samples. The surface morphologies of the calcined samples were different from those of the raw materials. The EDS analysis results indicate that there are $\mathrm{CaO}-\mathrm{MgO}$ composite and $\mathrm{CaO}$ phase, being consistent with $\mathrm{XRD}$ analysis results.

3.3. Carbonation of Pyrolysis Products of Dolomite. TG-DTA curves of the pyrolysis products of dolomite heated to $1273 \mathrm{~K}$ in an atmosphere of $\mathrm{CO}_{2}$ are shown in Figure 7. The products were able to absorb $\mathrm{CO}_{2}$ between temperatures of 600 and $1100 \mathrm{~K}$. Figure 4 indicates that only $\mathrm{CaO}$ reacted with $\mathrm{CO}_{2}$

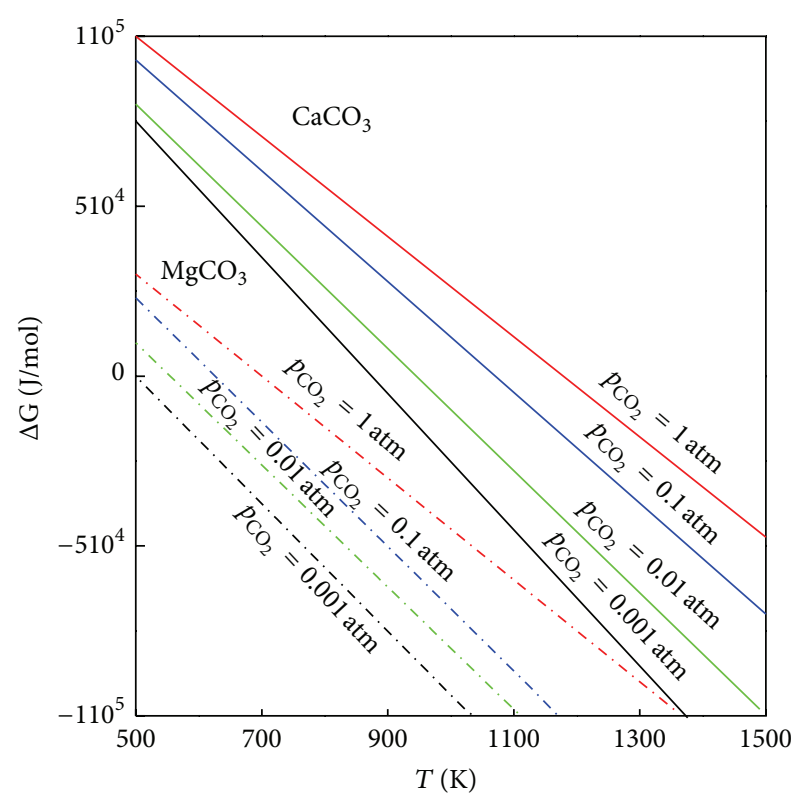

Figure 4: The Gibbs free energy changes of the decomposition reaction of $\mathrm{CaCO}_{3}$ and $\mathrm{MgCO}_{3}$ at $\mathrm{PCO}_{2}=0.001 \sim 1 \mathrm{~atm}$.

at these conditions. Previous studies $[7,18]$ also ratify this fact that $\mathrm{MgO}$ contained in calcined dolomite does not contribute to $\mathrm{CO}_{2}$ absorption. However, inert $\mathrm{MgO}$ stabilizes the structure of the solid sorbent during cyclic absorption and release procedures. Therefore, the stability of dolomite structure is attributed to the "excess" pore volume created by the original decomposition of $\mathrm{MgCO}_{3}$ in dolomite $[7,18]$.

Figure 8 shows the results of the cyclic degree of absorption tests. The degree of absorption of the dolomite samples calcined in an Ar atmosphere was $43 \%$ for the 1st cycle, $24 \%$ for the 2 nd cycle, and $19 \%$ for the 3rd cycle. On the other hand, the degree of absorption of the dolomite sample calcined in vacuum was 51,42 , and $30 \%$ for the 1 st, 2nd, and 3rd cycles, respectively. These values are clearly higher than those of the dolomite sample calcined in the Ar atmosphere because of the bigger specific surface area and higher micropore volume obtained.

Figure 9 shows variation of the specific surface area and micropore volume of calcined dolomite samples on cyclic absorption and release procedures. As can be seen, the higher absorption capacity of the dolomite sample calcined in vacuum is due to its high specific surface area and pore volume. Regardless of the calcination conditions used, the degree of absorption of the pyrolysis products of dolomite decreased with repeated cycling of the $\mathrm{CO}_{2}$ absorption and release procedures. Though, the specific surface area of $\mathrm{CO}_{2}$ released samples $\left(R_{n}\right)$ increased under repeated cycling, the pore volume did not increase. It is surmised that the difference between the expansion coefficients of $\mathrm{MgO}(10.5 \times$ $\left.10^{-6}\right), \mathrm{CaO}\left(13.6 \times 10^{-6}\right)$, and $\mathrm{CaCO}_{3}\left(11.7 \times 10^{-6}\right)$ leads to the pulverization of the dolomite particles. On the other hand, this fact also suggests that no new pores are formed in the $\mathrm{CO}_{2}$ release process. 


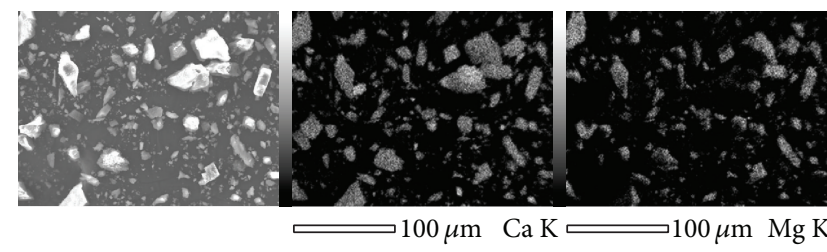

(a)

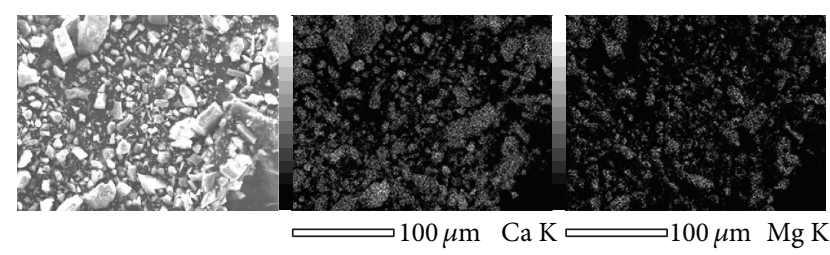

(b)

FIGURE 5: SEM micrographs and the energy-dispersive X-ray (EDX) analysis results of the dolomite pyrolysis products calcined in an Ar atmosphere (a) and vacuum (b).

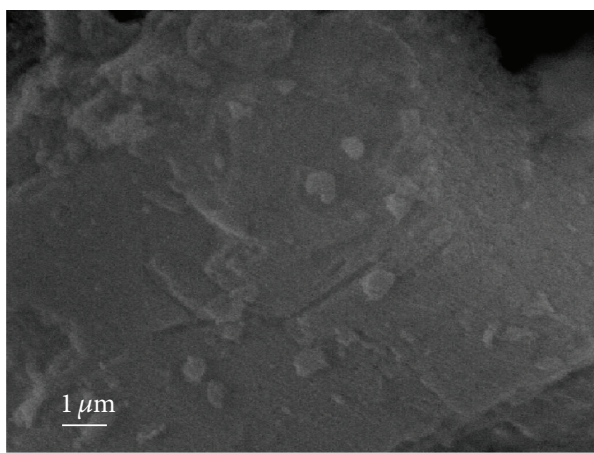

(a)

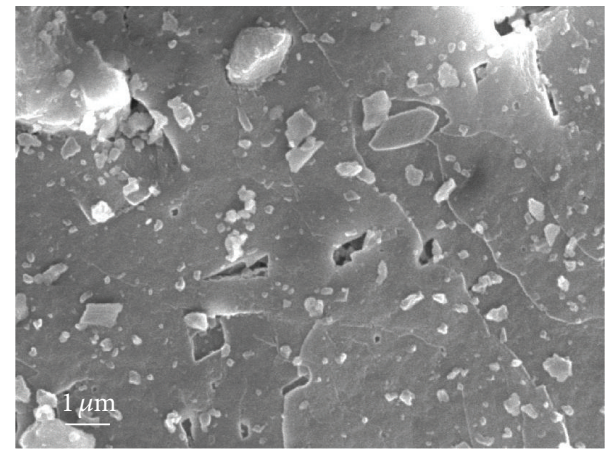

(b)

Figure 6: SEM micrographs of dolomite pyrolysis products ((a): Ar and (b): vacuum).

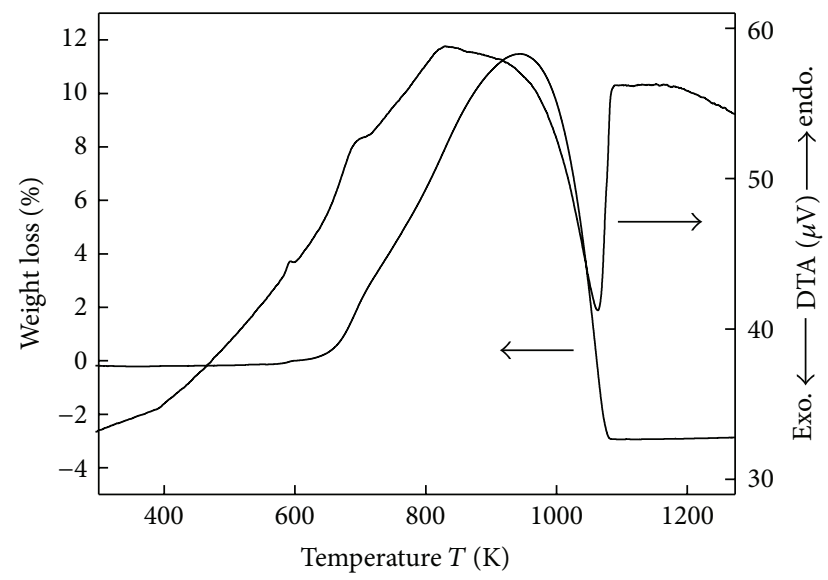

Figure 7: TG-DTA curves of dolomite pyrolysis products in $\mathrm{CO}_{2}$ atmosphere up to $1273 \mathrm{~K}$.

Figure 10 shows distributions of the micropore diameter of calcined dolomite fabricated in the Ar atmosphere and vacuum. This figure indicates that dolomite pyrolysis product fabricated in vacuum has micropores with larger diameter.

3.4. Discussion. The calcination of dolomite leads to the formation of the mixture of $\mathrm{CaO}$ and $\mathrm{MgO}$, which distribute uniformly in the pyrolysis product (see Figure 5). TG-DTA analysis revealed that only $\mathrm{CaO}$ can absorb $\mathrm{CO}_{2}$, while
$\mathrm{MgO}$ is not active for $\mathrm{CO}_{2}$. These results indicate that the absorption of $\mathrm{CO}_{2}$ proceeds via the intraparticle diffusion process, wherein $\mathrm{CO}_{2}$ gas diffuses through the micropores in the $\mathrm{CaCO}_{3}$ and $\mathrm{MgO}$ mixture layer. On the absorption of $\mathrm{CO}_{2}$, the $\mathrm{CaO}$ phase expands leading to the blockage of $\mathrm{CO}_{2}$ diffusion paths, resulting in reduction of the specific reaction interface area (see Figure 8). Therefore, to fabricate $\mathrm{CO}_{2}$ absorbents of high capacity, not only a large specific surface area but also large pore volume and pore diameters are required.

Calcination in vacuum can lead to absorbents having large specific surface area, pore volume, and pore diameter, because of the reduction of reaction temperature causing the dolomite particles to aggregate less.

\section{Conclusion}

The $\mathrm{CO}_{2}$ absorption and release properties of the pyrolysis products of dolomite were evaluated using thermogravimetry. Dolomite was decomposed completely on calcination at $1273 \mathrm{~K}$ in an $\mathrm{Ar}$ atmosphere and at $1073 \mathrm{~K}$ in vacuum into particles of $\mathrm{CaO}$ and $\mathrm{MgO}$. On subsequent absorption and release of $\mathrm{CO}_{2}$ in these particles, only $\mathrm{CaCO}_{3}$ was detected in the products along with unreacted $\mathrm{CaO}$ and $\mathrm{MgO}$. The degree of absorption of $\mathrm{CO}_{2}$ was higher for dolomite calcined in vacuum than that calcined in the Ar atmosphere. Furthermore, the degree of absorption of $\mathrm{CO}_{2}$ of the calcined particles of dolomite decreased with successive cycles of $\mathrm{CO}_{2}$ 


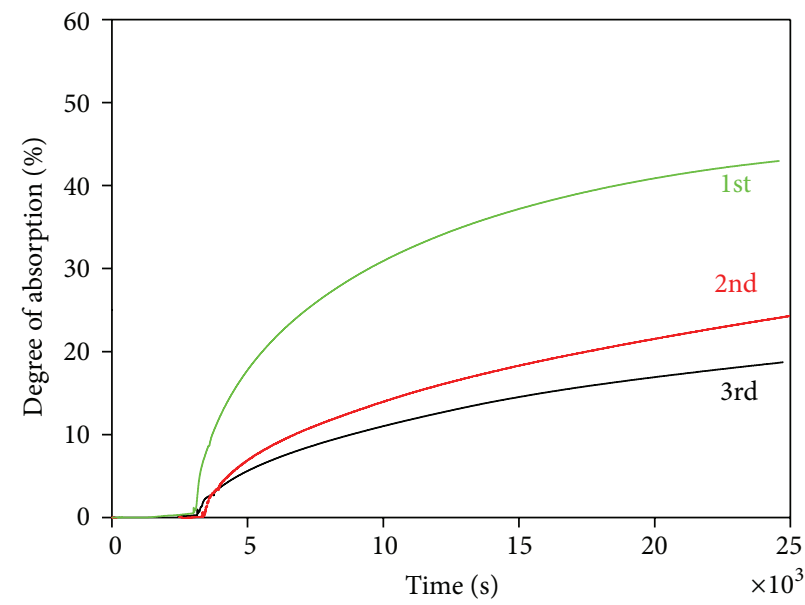

(a)

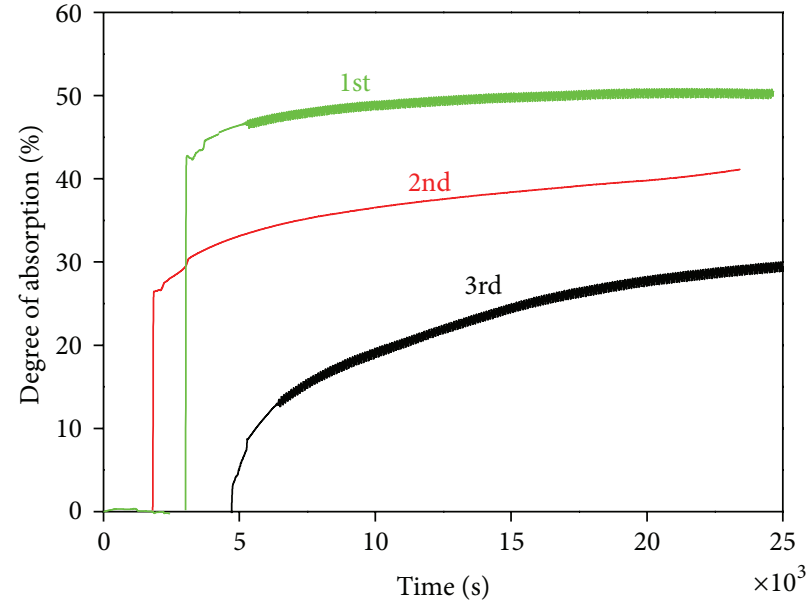

(b)

FIGURE 8: Cyclic degrees of absorption tests. (a): dolomite pyrolysis products calcined in Ar atmosphere; (b): calcined in vacuum.
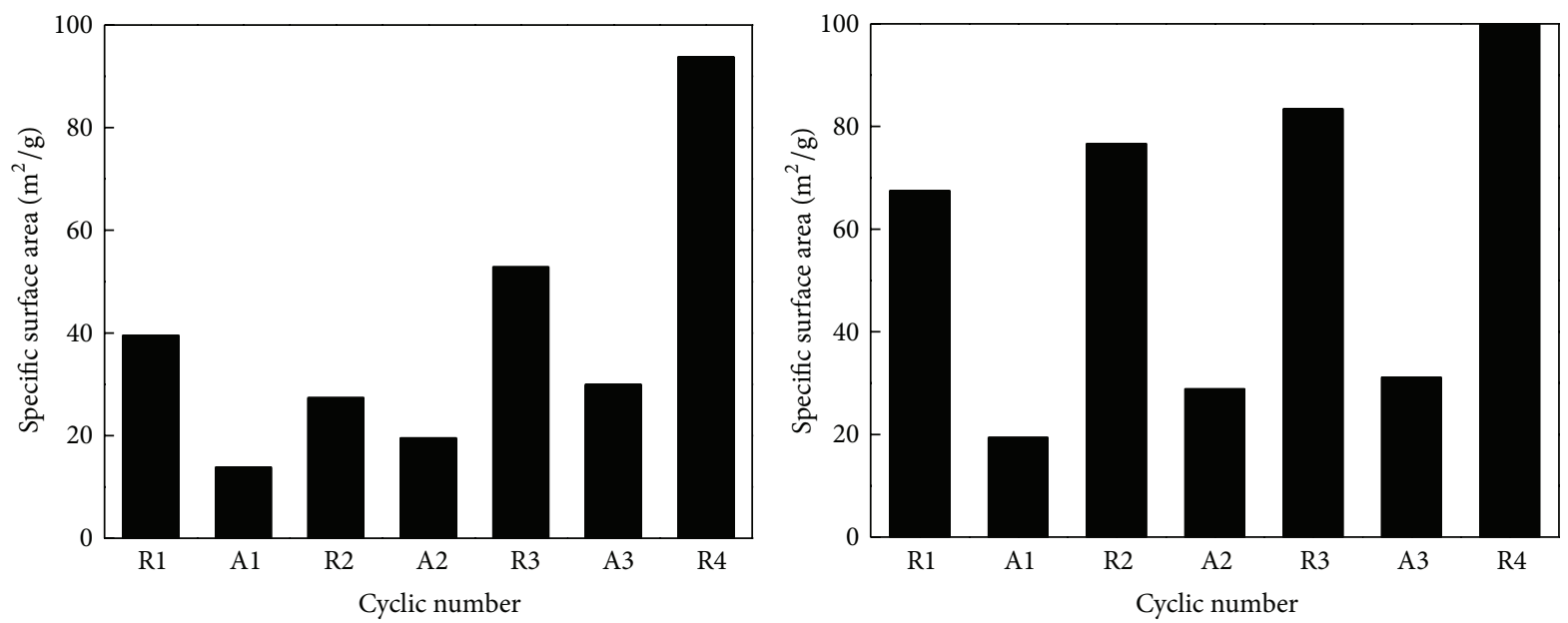

(1) Variation in specific surface area on repetition of the cyclic absorption and release procedures
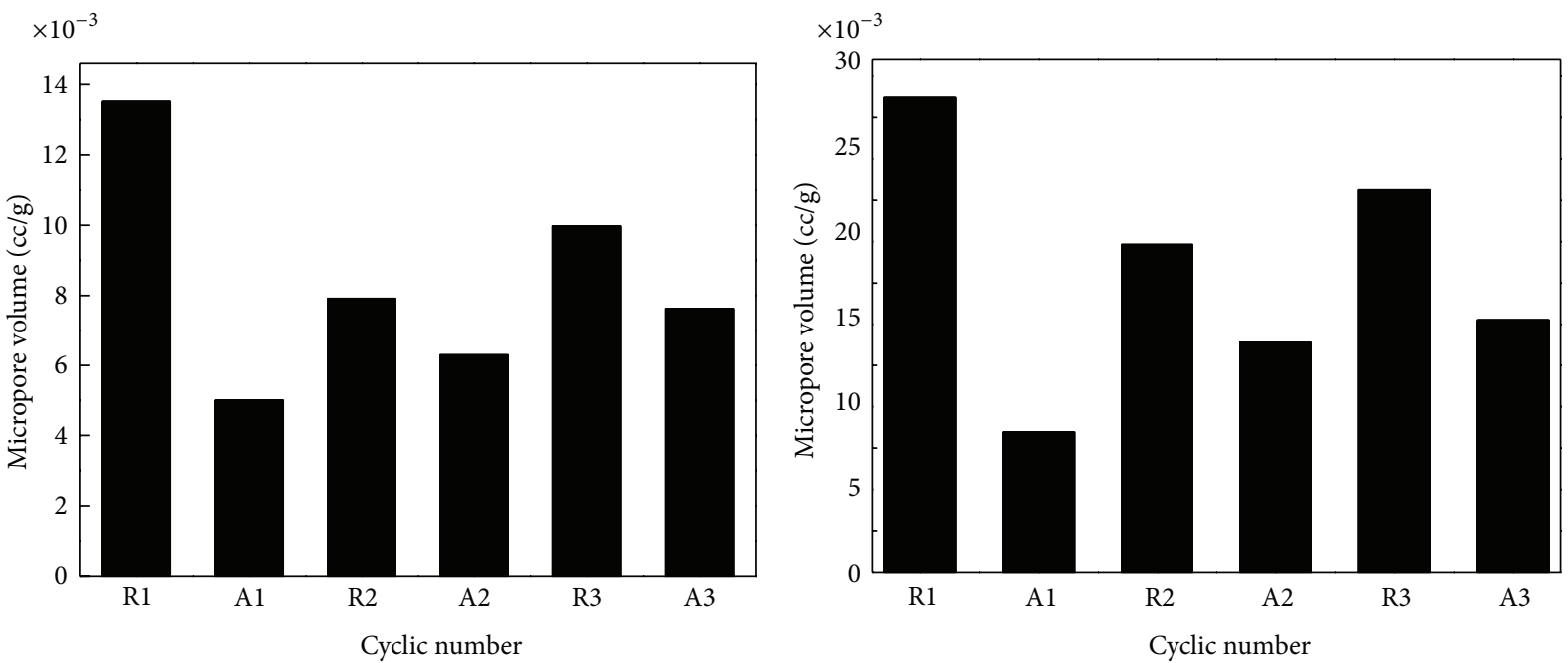

(2) Variation in micropore volume on repetition of the cyclic absorption and release procedures

FIGURE 9: Variation of the specific surface area and micropore volume of calcined dolomite samples on cyclic absorption and release procedures. Dolomite samples calcined in the Ar atmosphere and in vacuum (b) (R: after $\mathrm{CO}_{2}$ release; A: after $\mathrm{CO}_{2}$ absorption). 


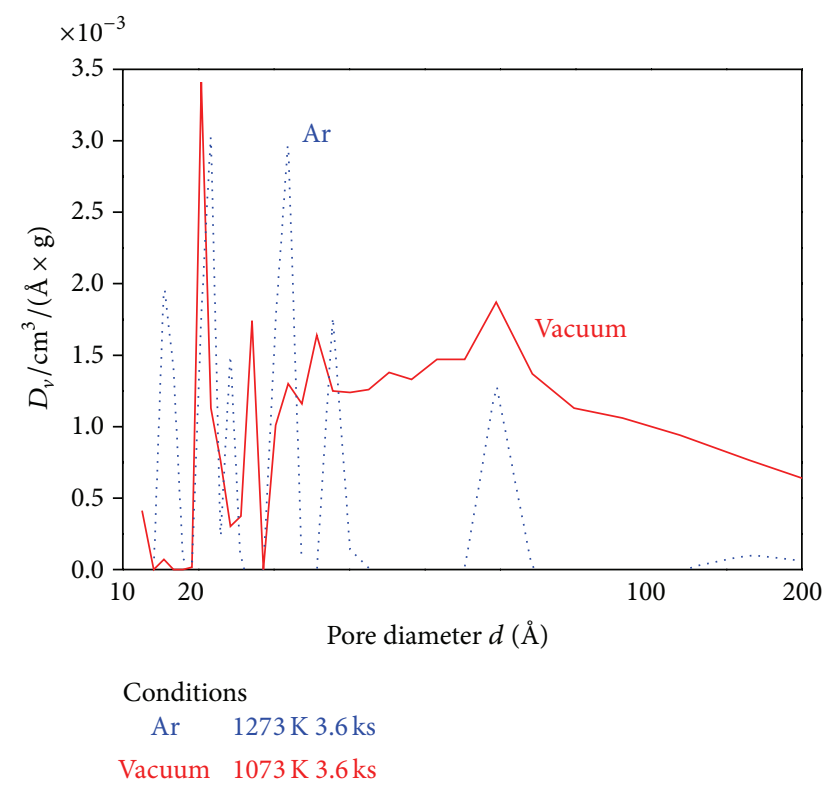

Figure 10: Pore diameter distribution of dolomite pyrolysis products.

absorption and release, because of the reduction of the size of the micropores in the particles.

\section{Conflict of Interests}

The authors declare that there is no conflict of interests regarding the publication of this paper.

\section{Acknowledgments}

This work was financially supported by Hainan Natural Science Foundation (Project no. 514218) and Major Science and Technology Projects of Hainan Province (ZDZX20130233).

\section{References}

[1] D. Bonenfant, L. Kharoune, S. Sauvé et al., "Molecular analysis of carbon dioxide adsorption processes on steel slag oxides," International Journal of Greenhouse Gas Control, vol. 3, no. 1, pp. 20-28, 2009.

[2] K. Chrissafis, C. Dagounaki, and K. M. Paraskevopoulos, "The effects of procedural variables on the maximum capture efficiency of $\mathrm{CO}_{2}$ using a carbonation/calcination cycle of carbonate rocks," Thermochimica Acta, vol. 428, no. 1-2, pp. 193198, 2005

[3] F. Wang, T. Kuzuya, and S. Hirai, "Improvement of $\mathrm{CO}_{2}$ absorption properties of limestone ore by the addition of reagent grade- $\mathrm{SiO}_{2}$ and natural diatomite," Materials Transactions, vol. 52, no. 12, pp. 2211-2215, 2011.

[4] P. Staszczuk, E. Stefaniak, B. Biliński, E. Szymański, R. Dobrowolski, and S. A. A. Jayaweera, "Investigations on the adsorption properties and porosity of natural and thermally treated dolomite samples," Powder Technology, vol. 92, no. 3, pp. 253-257, 1997.
[5] É. Kristóf-Makó and A. Juhász, “The effect of mechanical treatment on the crystal structure and thermal decomposition of dolomite," Thermochimica Acta, vol. 342, pp. 105-114, 1999.

[6] C. Rodriguez-Navarro, K. Kudlacz, and E. Ruiz-Agudo, "The mechanism of thermal decomposition of dolomite: new insights from 2D-XRD and TEM analyses," American Mineralogist, vol. 97, no. 1, pp. 38-51, 2012.

[7] H. Galai, M. Pijolat, K. Nahdi, and M. Trabelsi-Ayadi, "Mechanism of growth of $\mathrm{MgO}$ and $\mathrm{CaCO}_{3}$ during a dolomite partial decomposition," Solid State Ionics, vol. 178, no. 15-18, pp. 10391047, 2007.

[8] K. Gallucci, S. Stendardo, and P. U. Foscolo, " $\mathrm{CO}_{2}$ capture by means of dolomite in hydrogen production from syn gas," International Journal of Hydrogen Energy, vol. 33, no. 12, pp. 3049-3055, 2008.

[9] S. Stendardo and P. U. Foscolo, "Carbon dioxide capture with dolomite: a model for gas-solid reaction within the grains of a particulate sorbent," Chemical Engineering Science, vol. 64, no. 10, pp. 2343-2352, 2009.

[10] D. T. Beruto, R. Vecchiattini, and M. Giordani, "Effect of mixtures of $\mathrm{H}_{2} \mathrm{O}(\mathrm{g})$ and $\mathrm{CO}_{2}(\mathrm{~g})$ on the thermal half decomposition of dolomite natural stone in high $\mathrm{CO}_{2}$ pressure regime," Thermochimica Acta, vol. 404, no. 1-2, pp. 25-33, 2003.

[11] D. T. Beruto, R. Vecchiattini, and M. Giordani, "Solid products and rate-limiting step in the thermal half decomposition of natural dolomite in a $\mathrm{CO}_{2}(\mathrm{~g})$ atmosphere," Thermochimica Acta, vol. 405, no. 2, pp. 183-194, 2003.

[12] J. Ewing, D. Beruto, and A. W. Searcy, "The nature of $\mathrm{CaO}$ produced by calcite powder decomposition in vacuum and in $\mathrm{CO}_{2}$," Journal of the American Ceramic Society, vol. 62, pp. 580584, 1979.

[13] D. Beruto, L. Barco, and A. W. Searcy, " $\mathrm{CO}_{2}$-catalyzed surface area and porosity changes in high-surface-area $\mathrm{CaO}$ aggregates," Journal of the American Ceramic Society, vol. 67, pp. 512516, 1984.

[14] D. Beruto and A. W. Searcy, "Calcium oxides of high reactivity," Nature, vol. 263, no. 5574, pp. 221-222, 1976.

[15] G. D. Silcox, D. M. Slaughter, and D. W. Pershing, "High temperature sulfation studies in an isothermal reactor: a comparison of theory and experiment," Symposium (International) on Combustion, vol. 20, no. 1, pp. 1357-1364, 1985.

[16] I. Barin and O. Knacke, Thermochemical Properties of Inorganic Substances, Stahleisen m.b.H, Dusseldorf, Germany, 1973.

[17] I. Barin, O. Knacke, and O. Kubaschewski, Thermochemical Properties of Inorganic Substances, Stahleisen, Dusseldorf, Germany, 1977.

[18] L. Li, D. L. King, Z. Nie, and C. Howard, "Magnesia-stabilized calcium oxide absorbents with improved durability for high temperature $\mathrm{CO}_{2}$ capture," Industrial and Engineering Chemistry Research, vol. 48, no. 23, pp. 10604-10613, 2009. 

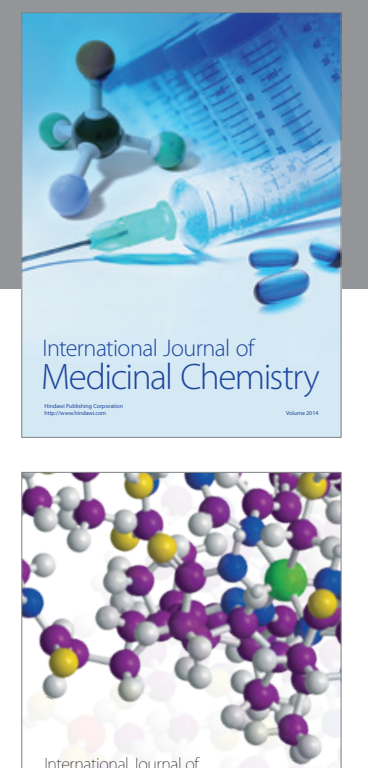

\section{Carbohydrate} Chemistry

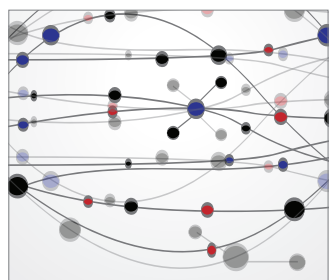

The Scientific World Journal
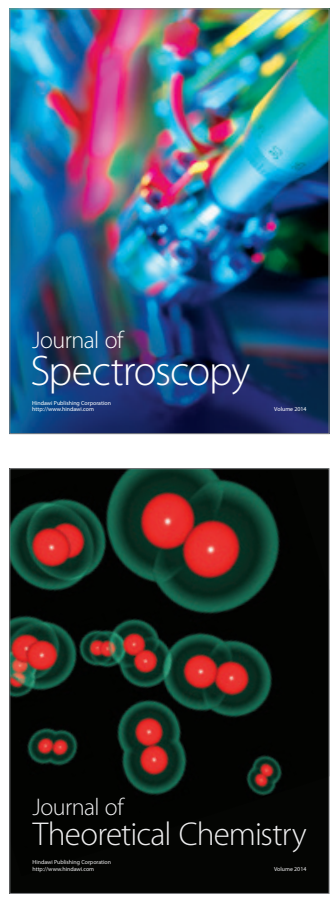
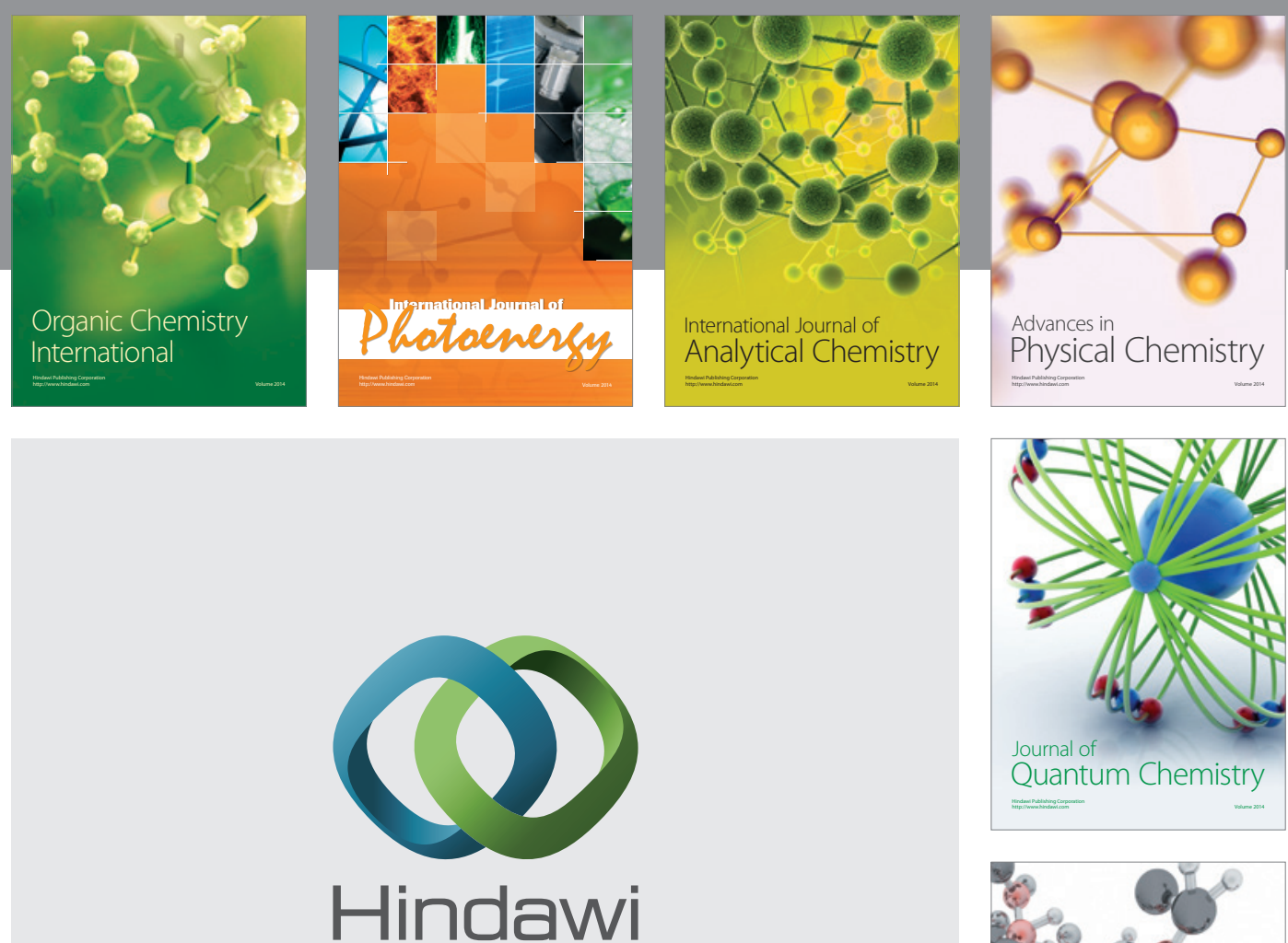

Submit your manuscripts at

http://www.hindawi.com

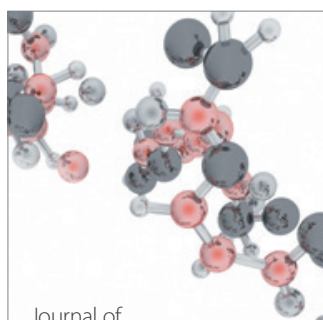

Analytical Methods

in Chemistry

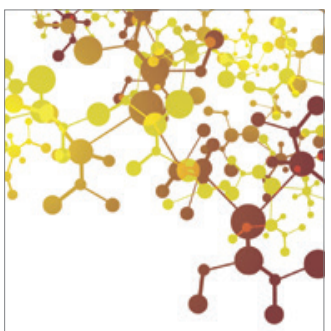

Journal of

Applied Chemistry

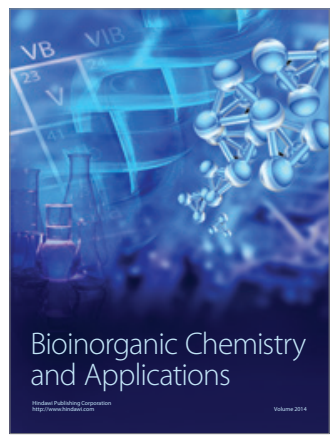

Inorganic Chemistry
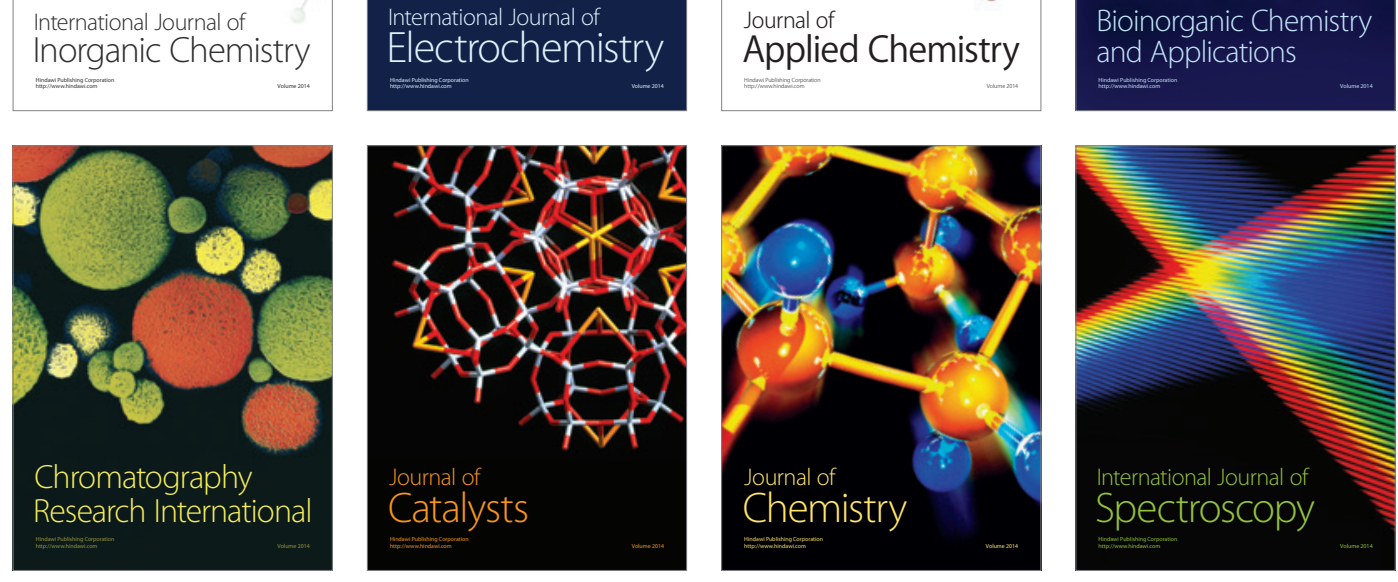